\title{
Guy Roger West MD, MSc, FRCPC September 24, 1935-December 3, 2017
}

\author{
Julie Anne Kromm
}

doi:10.1017/cjn.2018.339

Can J Neurol Sci. 2018; 45: 698-699

Guy (Roger) West passed away on December 3, 2017. A wellrespected neurologist and family man, he is missed by all. In the wake of our loss, we pause to reflect on his remarkable life.

Roger took an interesting path to neurology. He was born and raised on a farm near Strathmore, Alberta, and early on learned the value of hard work and the importance of family. With these morals ingrained, he briefly left high school, obtained a degree in Agricultural Management from Olds College, and started farming. Realizing the uncertainties of farming, he returned to complete high school in his early 20 s where he met Betty, his wife of 58 years. After graduation, Roger then set forth to start his family and become a doctor. The day his twin daughters were born, he learned he had been accepted to the University of Alberta Medical School, class of 1964.

Roger enlisted in the Canadian

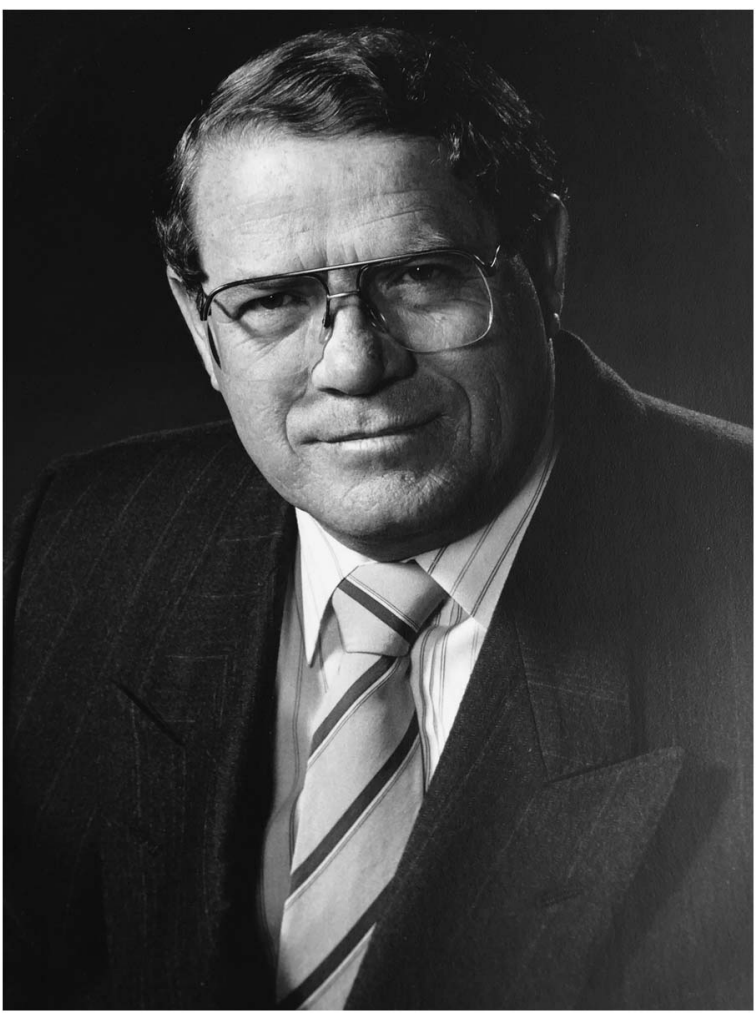

Roger was appointed as a clinical professor at the University of Calgary.

Throughout his career, Roger was involved in hospital administration. From 1974 to 1977 , he served as the Assistant Director of the Department of Medicine at the Calgary General Hospital, and in 1981 was appointed Chief of Staff. After his term as Chief, he subsequently served as Vice President, Medical Services from 1983 to 1993. During this time, his administrative duties were extended to include the newly built Peter Lougheed Hospital. While serving in these capacities, Roger was always prepared to take on new jobs and remained actively involved in many hospital committees serving as a chairman in several. Later in his career, he worked as a consultant for the Canadian Council of Health Services Accreditation, ensuring the deliverance of quality health care by hospitals nation-wide.

While Roger enjoyed his administrative responsibilities, he was Navy after his first year of medical school and served as a Surgeon Lieutenant upon completion of his medical training from 1965 to 1968. Originally stationed at Esquimalt Navy Base, he was later transferred north to Holberg Royal Canadian Air Force Base, British Columbia. There, he served as a general practitioner in the truest sense - tending to minor ailments, major illnesses, delivering babies, and performing minor surgeries. Being the only physician for the Air Force Base and logging communities of Northern Vancouver Island, not only did he serve as the base doctor but also the hospital administrator and at times the base veterinarian.

During his medical school training and military service, Roger and Betty welcomed three more children to their family. In 1968, they returned to Edmonton where Roger completed his Master of Science (1969) and Neurology Residency (1972) at the University of Alberta. In 1973, he and his family moved to Calgary, where always happiest at the bedside treating patients. His fervor for neurology remained throughout his career as he was always edge. While he considered himself a general neurologist, despite a full-time practice and heavy administrative commitments, he continued to train in electromyography, obtaining his Certification from the Canadian Society of Neurophysiology in 1993. Thereafter, he was instrumental in expanding the EMG labs at

From the Departments of Critical Care Medicine \& Clinical Neuroscience, University of Calgary, Calgary, Alberta, Canada

Received August 1, 2018. Date of Acceptance August 5, 2018.

Correspondence to: Julie Anne Kromm, Department of Critical Care Medicine, McCaig Tower, Foothills Medical Centre, 3134 Hospital Drive NW, Calgary, Alberta T2N 5A1, Canada.

Email: jkromm@ualberta.ca reading and attending courses in an attempt to better his knowl- 
both the Calgary General Hospital and the Foothills Medical Centre.

Roger loved sharing his knowledge with others. He was committed to providing quality education and mentorship for trainees just as he had received during his training. He was actively involved in the Association of Canadian Teaching Hospitals from 1983 to 1993 and was appointed president from 1988 to 1992 . During this time, he also assisted the Canadian Medical Association draft guidelines for resident program responsibilities. Many other years of his career were spent serving on the University of Calgary Cummings School of Medicine Graduate Continuing Education Committee. At an individual level, Roger was always happy to have residents working alongside him, and volunteered to help teach neuro-anatomy to undergraduate medical students even after he retired from his clinical responsibilities.

In his spare time, Roger enjoyed spending time with family and friends. Wanting to impart the importance of family to his children, he always found time during his training and busy career for family activities. In the winter, he could be found at the curling rink enjoying a friendly competition between colleagues, and in summer golfing with friends. His talent for wood working provided several pieces of furniture and decorative birds to adorn his own, his children's, and his grandchildren's homes. Traveling was also a passion of his, as he and Betty visited several countries throughout their life together. Once retired from neurology Roger returned to his roots, spending time with family and working hard helping his grandchildren on their farm.

Roger will be remembered by colleagues and past students as a humble, hardworking, committed administrator, respected teacher, and caring clinician. His friends and family will never forget his youthfulness, good humor, and kind heart. As his granddaughter and now a neurologist, I fondly remember nights where he would spend time sharing his knowledge and telling me stories of his career while eating ice cream together. While I kept my relation quiet in the early part of my career not wanting to benefit from his success, I now see that there is no greater honor than to be known as Roger West's granddaughter. He is greatly missed.

\section{Disclosures}

Dr. Kromm reports that Dr. West was her grandfather.

\section{Statement OF Authorship}

The author researched information, drafted, and edited manuscript.

Julie Anne Kromm

Departments of Critical Care Medicine \& Clinical Neuroscience

University of Calgary, Calgary, Alberta, Canada 